\title{
DNA VARIATION AND RIBOSOMAL-DNA CONSTANCY IN TWO CREPIS SPECIES AND THE INTERSPECIFIC HYBRID EXHIBITING NUCLEOLAR-ORGANISER SUPPRESSION*
}

\author{
EARLE B. DOERSCHUG \\ Department of Genetics, lowa State University, Ames, lowa 50011 \\ JEROME P. MIKSCHE \\ Institute of Forest Genetics, North Central Forest Experiment Station, \\ Rhinelander, Wisconsin 54501 \\ and \\ HERBERT STERN \\ Department of Biology, University of California at San Diego, La Jolla, California 92037

\section{Summary} \\ The interspecific hybrid between Crepis capillaris and $C$. dioscorides exhibits \\ suppression of the secondary constriction in the chromosome derived from \\ C. dioscorides; each species normally has one chromosome pair with secondary \\ constrictions. Such structures are known to be associated with the formation of \\ nucleoli and are the probable sites of ribosomal-DNA (rDNA). The two species \\ and the hybrid were studied with respect to DNA and rDNA variation to \\ determine whether reduction of the highly redundant rDNA might occur as a \\ consequence of nucleolar organiser suppression. \\ The DNA content of $C$. dioscorides was three times greater than of $C$. capillaris. \\ This is consistent with trends in the genus Crepis. Evolutionary advancement \\ is correlated with a reduction of both chromosome number $(C$. dioscorides, \\ $2 n=8$; C. capillaris, $2 n=6$ ) and chromosome size. The chromosomes of the \\ more advanced species, $C$. capillaris, are smaller than those of $C$. dioscorides. \\ No alterations of the parental contributions of rDNA were observed in the \\ hybrid, however; the two species and the hybrid each contained about \\ $5000 \mathrm{rRNA}$ genes. It was concluded that nucleolar organiser suppression must \\ be at the transcription level.
}

Received 24.ii.76

\section{INTRODUCTION}

THE DNA (rDNA) complementary to 18 and 28S ribosomal RNA (rRNA) is located in the region of the nucleolar organiser (NOR) in Drosophila (Ritossa and Spiegelman, 1965), Xenopus (Wallace and Birnstiel, 1966) and maize (Phillips et al., 1971) and to the nucleolus organising body itself and the distal achromatic gap of the maize chromosome (Givens, 1974; Ramirez and Sinclair, 1975; Doerschug, 1976). The redundancy in rDNA cistrons and the broad variation in degree of redundancy have been demonstrated in many higher organisms. Years ago, Navashin (1934) described a striking relationship between the number of chromosomes bearing a secondary constriction formed in hybrids of Crepis and the source of parental chromosomes. Normally there are two such chromosomes in diploid plants and animals; these were named SAT chromosomes since the secondary constriction seemingly lacked nucleic acid (sine acido thymo nucleinico) (Heitz,

* Journal Paper No. J-8401 of the Iowa Agriculture and Home Economics Experiment Station, Ames, Iowa. Project No. 1880. 
1931). In certain interspecific hybrids secondary constriction formation was suppressed in the SAT chromosome from one of the parental species. The affected chromosome was always from the same parental species in a given cross. A hierarchy of dominance existed such that within a hybrid secondary constriction formation was suppressed in the chromosome contributed by the species of lower rank. Recently Wallace and Langridge (1971) showed that, in the hybrid C. neglecta-capillaris, the nucleolus was always associated with the SAT chromosome of $C$. capillaris and not with that of $C$. neglecta. They attributed the observed behaviour to a repression of RNA transcription in the NOR of the C. neglecta genome. We have explored the possibility that the absence of a secondary constriction in the apparently repressed NOR-bearing chromosome with Crepis hybrids might be due to an elimination of the redunandant rDNA genes subsequent to fertilisation. This latter interpretation seemed tenable since increases or decreases of rDNA are known to occur (Ritossa, 1968; Tartoff, 1971, 1973). Our studies were based on analysis of DNA and rDNA gene levels in Crepis capillaris, $C$. dioscorides, and the interspecific hybrid. Our results clearly indicate that there is no rDNA loss, and unexpectedly that the two species contain the same number of rDNA genes even though one contains almost three times as much DNA.

\section{Materials AND methods}

(i) Propagation of Crepis species and genetic crosses

Seeds of Crepis capillaris were obtained from G. L. Stebbins, University of California, Davis, and the Botanisk Have, Copenhagen. Crepis dioscorides was also obtained from the latter source. The plants were grown in growth chambers and the greenhouse and genetic crosses were made according to the methods of J. L. Collins (1922). C. capillaris was used as the female parent in crosses with $C$. dioscorides because of its self-incompatibility, whereas $C$. dioscorides is partly self-fertile.

\section{(ii) Cytogenetic analysis}

The karyotypes of the parent species and the interspecific hybrid were determined as follows: Vigorous young root tips were excised and placed in freshly prepared $0 \cdot 002 \mathrm{M} 8$-hydroxyquinoline for 3 hours at $16-18^{\circ} \mathrm{C}$. (Tjio and Levan, 1950). The tips were rinsed and fixed overnight in 3 parts 95 per cent ethanol: 1 part glacial acetic acid. Cytological preparations were made by the Feulgen Squash Method (Darlington and LaCour, 1962); maceration by hydrolysis in $\mathrm{N} \mathrm{HCl}$ at $60^{\circ}$ for 7 minutes, staining in Schiff's Reagent 1-3 hours followed by tapping the coverslip directly over the root tip (Ghidoni, Achille, personal comm.) that had been placed in a drop of acetic-orcein ( 1 per cent in 45 per cent acetic acid). The preparation was pressed to flatten the cells and sealed. Many late-prophase and metaphase figures were clearly observed.

\section{(iii) Culture of Crepis capillaris}

Sterile cultures of Crepis capillaris were initiated and grown in the basal medium designed by Eriksson (1965) supplemented with $10 \mathrm{mg} / 1$ myoinositol and $50 \mathrm{ml} / 1$ coconut milk. They were grown in the dark at room 
temperature (about $21^{\circ}-23^{\circ} \mathrm{C}$ ) and consisted predominantly of masses of buds on a callus base. The cultures were used for the incorporation of ${ }^{32} \mathrm{P}$ orthophosphate to keep the plant material free of contaminating bacteria and fungi.

\section{(iv) $D \mathcal{N A}$ isolation}

After exposure to "long day" photoperiods (16 hours light, 8 hours dark) after a short day regime (10 hours light, 14 hours dark), Crepis plants bolt by producing a profusion of buds. These buds, which are masses of compact cells, were collected, and DNA was isolated by a modification of the method of Hotta et al. (1965). Tissues were ground in ethanol cooled to $-20^{\circ} \mathrm{C}$ in a ground-glass homogeniser until the homogenate consisted of broken cells, single and small clumps of cells. After washing two times with 70 per cent ethanol, the cells were disrupted by stirring them into 2 volumes of 1 per cent sodium lauryl sulfate (SLS), $0.01 \mathrm{M}$ ethylenediaminetetraacetic acid (EDTA) and $0 \cdot 05 \mathrm{M}$ Tris buffer, $p \mathrm{H} 8 \cdot 5$. The mixture was heated rapidly to $65^{\circ} \mathrm{C}$ and maintained for 20 minutes, followed by centrifugation and re-extraction of the pellet with an aliquot of the original extraction fluid. Two volumes of 95 per cent ethanol were mixed and the precipitate collected by centrifugation. After washing two times with 70 per cent ethanol, the precipitate was redissolved by slow stirring at room temperature in $0.01 \mathrm{M}$ Tris $p \mathrm{H} 7.5,0.01 \mathrm{M} \mathrm{EDTA,} \mathrm{lm} \mathrm{NaCl}$, and $1 \mathrm{mg} / \mathrm{ml}$ of pronase (the enzyme solution had been pretreated at $65^{\circ} \mathrm{C}$ for 10 minutes to remove contaminating deoxyribonucleases). After incubation for at least 4 hours, the solution was deproteinised two times with chloroform: isoamyl alcohol $(24: 1 \mathrm{v} / \mathrm{v})$. The DNA in this and subsequent steps was "spooled out" by slowly adding 0.55 volumes of isopropanol. The remainder of the purification was according to Marmur (1961) and included two ribonuclease treatments $\left(50 \mu \mathrm{g} / \mathrm{ml}, 15\right.$ minutes, $\left.37^{\circ} \mathrm{C}\right)$ followed by an additional pronase treatment $\left(200 \mu \mathrm{g} / \mathrm{ml}, 2\right.$ hours, $\left.37^{\circ} \mathrm{C}\right)$ and extraction with chloroform: isoamyl alcohol until no precipitate formed at the interface. After the final precipitation with isopropanol, the DNA was stored in 95 per cent ethanol at $-20^{\circ} \mathrm{C}$.

\section{(v) $R \mathcal{N} A$ isolation}

Ribosomal-RNA was isolated by an adaptation of the method of Kirby (1965). The sterile ${ }^{32}$ P-labelled bud material was washed thoroughly with water, drained, weighed, and frozen in liquid nitrogen. After grinding with a frozen mortar and pestle, the tissue powder was homogenised ( 3 times, 1 minute each) at three-fourths maximum speed in a Virtis cup containing 0.5 per cent disodium naphthalene disulphonate in 0.05 Tris $p \mathrm{H} 7.6$ (5 volumes) and phenol-cresol mixture (5 volumes). The latter contained $550 \mathrm{ml}$ water-saturated phenol (freshly distilled), $70 \mathrm{ml}$ cresol (freshly distilled, colourless), and $0.5 \mathrm{~g}$ 8-hydroxyquinoline. After high-speed blending the mixture was shaken vigorously for 20 minutes, chilled, and centrifuged in a Sorvall angle head (15,000 r.p.m., 15 minutes). The aqueous layer was made 3 per cent in sodium chloride, l per cent in triisopropyl-naphthalene-sulfonate (TIPNS), and shaken twice with phenolcresol before precipitating with 2.5 volumes of 80 per cent ethanol containing 
$0 \cdot 02 \mathrm{M}$ potassium acetate. The mixture was stored in the freezer for at least 2 hours to obtain full precipitation of the RNA. The precipitate was collected, washed with 70 per cent ethanol and redissolved in a small volume of 1 per cent TIPNS, $0.01 \mathrm{~m}$ Tris $p \mathrm{H} 7 \cdot 6$, and an equal volume phenol-cresol mixture. After dissolving, the aqueous portion was made 3 per cent in sodium chloride. The mixture was shaken and centrifuged as before until no material remained at the interface. The RNA was precipitated, stored, collected, washed and dissolved in $0.05 \mathrm{M}$ Tris with $3 \mathrm{mM} \mathrm{MgCl}_{2}$ and $20 \mu \mathrm{g} / \mathrm{ml} \mathrm{DNase}$ (electrophoretically pure) for 15 minutes at $37^{\circ} \mathrm{C}$. The RNA solution was diluted with $0.05 \mathrm{~m}$ phosphate buffer and immediately added to a MAK column (Sueoka and Cheng, 1962), washed and eluted with a $150 \mathrm{ml}$ linear gradient $(0 \cdot 4 \mathrm{M}$ to $1 \cdot 2 \mathrm{M}$ sodium chloride in $0 \cdot 05 \mathrm{M}$ phosphate buffer). The ribosomal RNA eluted as a single peak at about 0.8 sodium chloride. The fractions were pooled and the RNA dialysed against two litres $2 \times$ SSC for 24 hours (SSC contains $0 \cdot 15 \mathrm{~m}$ sodium chloride and 0.015 sodium citrate). The RNA was used only if it was stable at $65^{\circ} \mathrm{C}$ for the duration of the hybridisations and if it contained less than 0.05 per cent base stable material (detected by treating a portion of the RNA with $0 \cdot 2 \mathrm{~N}$ sodium hydroxide for 20 minutes at $70^{\circ}$ and comparing trichloroacetic acid precipitable counts before and after hydrolysis (Gillespie and Spiegelman, 1965).

\section{(vi) Molecular hybridisations}

The DNA's were denatured with alkali and bound to nitrocellulose membrane filters (type B-6, Schleicher and Schuell) with $30 \mu \mathrm{g}$ DNA per filter (determined by optical density before and after loading) according to the method of Gillespie and Spiegelman (1965). Saturation-type hybridisation reactions were performed according to the method of these authors using the rRNA concentrations specified. The reactions were carried out in $2 \times \mathrm{SSG}$ at $65^{\circ} \mathrm{C}$ for 15 hours. A blank and a DNA filter were incubated in each vial. The filters were then washed, treated with RNase $(20 \mu \mathrm{g} / \mathrm{ml}, 1$ hour $)$ and washed again with $2 \times \mathrm{SSC}$, after which they were dried and counted.

To compensate for differential retention of the DNA by the filters, the amount of DNA on each filter was determined after the hybridisation reactions. The filters were washed several times in chloroform to remove the toluene and fluors and then air dried. Each filter was cut into small pieces, placed in a tube with $1 \mathrm{ml} 5$ per cent perchloric acid, sealed, and hydrolysed for 20 minutes at $70^{\circ} \mathrm{C}$. The amount of DNA in each sample was determined by the diphenylamine reaction (Burton, 1968). A standard curve was prepared with blank filters to correct for colour absorption.

\section{(vii) $D \mathcal{N} A$ determination}

Chicken erythrocytes, which served as an internal standard, were smeared on microscope slides. The slides and excised root tips were fixed in Carnoy's fixative for 3 hours and rinsed several times in 70 per cent ethanol. The root tips and erythrocyte smears were hydrolysed for 20 minutes in $5 \mathrm{~N} \mathrm{HCl}$ at room temperature. The root tips were squashed on a cleared area of the smear slides. 

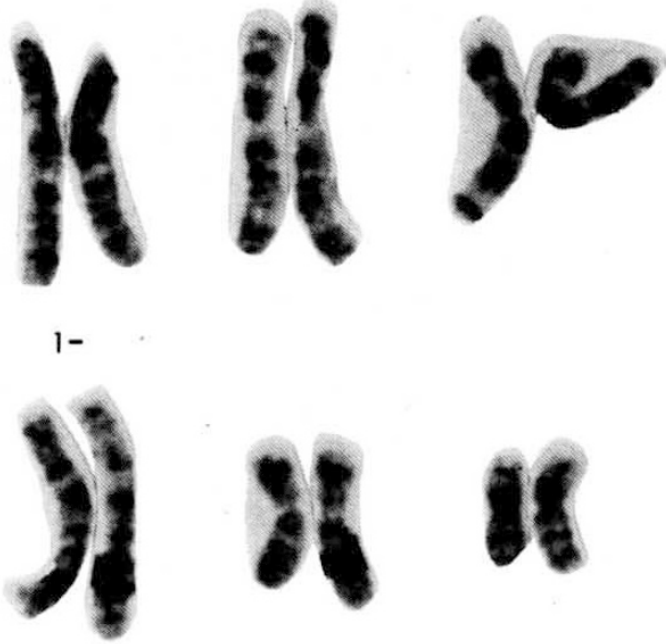

is

li

4

(1)

1

al

68

9

$2 \times$

$-13$

$\begin{array}{lll}x_{1} & x_{2} & y\end{array}$

P.

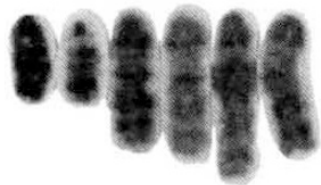

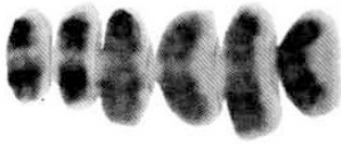

7-

Hagst

atsate

เ8948

908918

(2) -13 ate

$x_{1}$ exis.

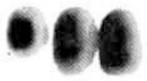

$x_{2}$
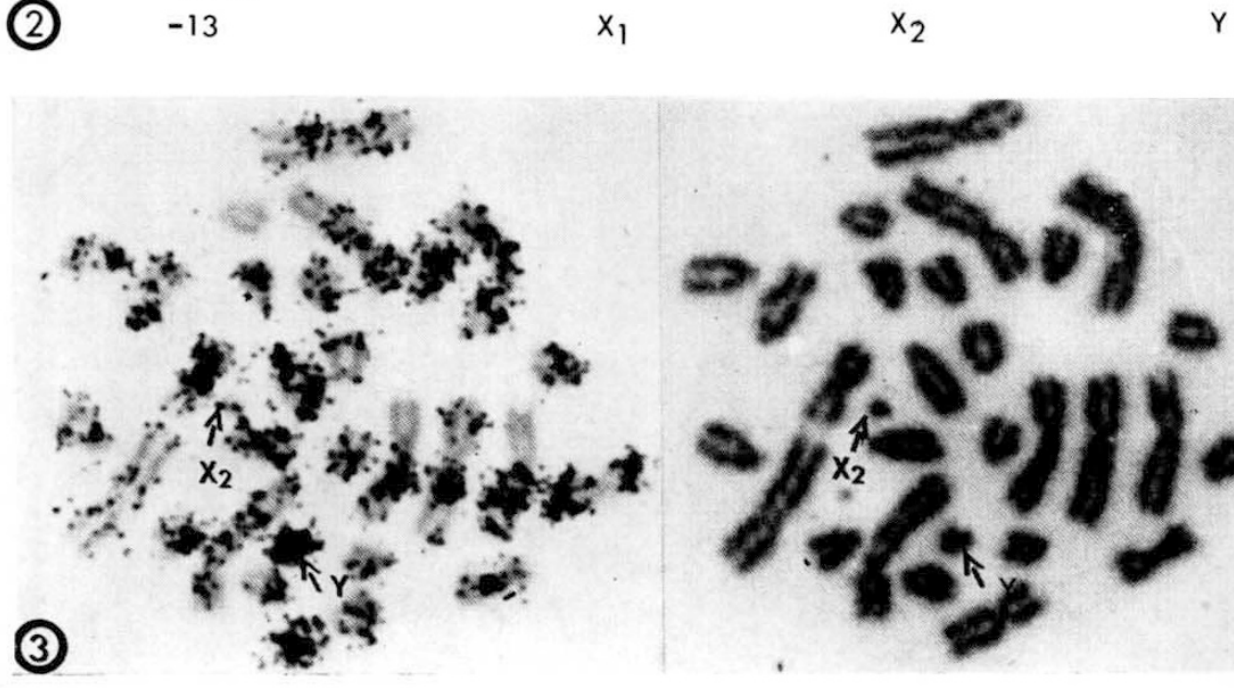

(2)

(2) $x+2 \%$
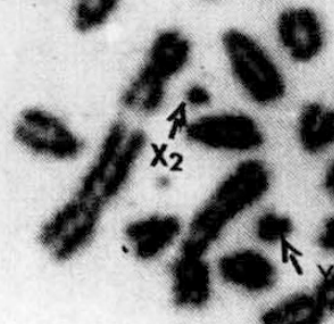
The erythrocyte nuclear dry mass was determined from 150 polarising interference microscope readings by using the formula given by Berlyn and Miksche (1976). The procedure was repeated after treating the cells with DNase, the difference in dry weights representing the amount of DNA/nucleus.

The cells were stained with Schiff's reagent, and cytophotometric absorbancies were determined as described by Jacqmard et al. (1972) and Berlyn and Miksche (1976). The ratio of nuclear dry mass to Feulgen absorption in erythrocyte nuclei was used to calculate the absolute amounts of DNA in Crepis nuclei. The DNA content of erythrocyte nuclei as determined by inteferometry $\left(2 \cdot 62 \times 10^{-12} \mathrm{~g}\right)$ is close to published values determined chemically (Sober, 1970).

\section{Results}

(i) The cytogenetics of nucleolar organiser suppression in an interspecific hybrid

Interspecific hybrids were made between Crepis capillaris (우) and Crepis dioscorides. The results of Navashin (1934) were confirmed by examining the chromosomes of the hybrids and the parental species. The chromosome number of $C$. capillaris is $2 n=6$ and that of $C$. dioscorides is $2 n=8$, causing hybrids to have a total of 7 chromosomes; thus the hybrids were easily distinguished cytogenetically from self-pollinated contaminants of C.capillaris. Two homologous satellited chromosomes always were observed in cytological preparations of the parental species (plate I). In all 25 hybrid plants (7 chromosomes), one of the normally satellited chromosomes had no satellite; instead the terminal chromosomal segment was indistinguishable from the main body of the acrocentric chromosome (plate I). The NOR-bearing chromosomes of the two species are easily distinguished in the hybrids because the SAT chromosome derived from $C$. capillaris is shorter than that from $C$. dioscorides. In every hybrid plant the satellite was missing from the putative SAT chromosome derived from the $C$. dioscorides parent.

\section{(ii) $D \mathcal{N A}$ contents and number of $r R \mathcal{N} A$ genes}

The nuclear DNA contents of $C$. dioscorides, C. capillaris and C. dioscorides $\times$ capillaris, as determined by microspectrophotometry are listed in table 1. The ratio in values obtained for metaphase and telophase cells are approximately 2 for all the plant types, thus pointing to the validity of the method for determining the relative DNA contents of species and hybrid. The data indicate that $C$. dioscorides has about $2 \cdot 8$ times as much DNA as $C$. capillaris even though the two species differ by only one chromosome in their haploid number. The absolute diploid DNA values are about $11 \mathrm{pg}$ for $C$. dioscorides, $4 \mathrm{pg}$ for $C$. capillaris and, as expected, $8 \mathrm{pg}$ for the hybrid. These values are used in subsequent calculations of rDNA content per genome.

Molecular hybridisation experiments (Gillespie and Spiegelman, 1965) were performed with ${ }^{32} \mathrm{P}-\mathrm{rRNA}$ extracted from sterile cultures of Crepis capillaris which had been grown for two weeks in a medium containing $25 \mu \mathrm{c} / \mathrm{ml}$ inorganic ${ }^{32} \mathrm{P}$-phosphate. The saturation levels for rRNA/DNA hybridisations in each of the parent species and in the interspecific hybrid 
are recorded in fig. 1. Ribosomal-DNA accounts for 0.4 per cent of the total DNA in C. capillaris, $0 \cdot 15$ per cent in $C$. dioscorides, and 0.2 per cent

TABLE 1

The relative and absolute DNA contents of Crepis capillaris, C. dioscorides, and the interspecific hybrid. The 2c (telophase) and $4 c$ (metaphase) amounts of DNA were determined by comparing microspectrophotometer absorbancies of root cell nuclei with chicken erythrocyte nuclei which contain the $2 c$ amount of DNA $(2.62 \mathrm{pg})$ as determined by interference microscopy. Fifty cells of each type were measured

\begin{tabular}{|c|c|c|c|c|c|c|}
\hline \multirow[b]{2}{*}{ Source } & \multirow[b]{2}{*}{ Test } & \multicolumn{2}{|c|}{ Metaphase } & \multicolumn{2}{|c|}{ Telophase } & \multirow{2}{*}{$\begin{array}{c}\text { Erythrocyte } \\
\text { Relative } \\
\text { absorbance }\end{array}$} \\
\hline & & $\begin{array}{c}\text { Relative } \\
\text { absorbance* }\end{array}$ & $\begin{array}{c}\text { DNA (4c) } \\
(\mathrm{pg})\end{array}$ & $\begin{array}{c}\text { Relative } \\
\text { absorbance }\end{array}$ & $\begin{array}{c}\text { DNA (2c) } \\
(\mathrm{pg})\end{array}$ & \\
\hline C. capillaris & $\begin{array}{l}1 \\
2\end{array}$ & $\begin{array}{l}34 \cdot 0 \pm 0 \cdot 7 \\
34 \cdot 0 \pm 0 \cdot 7\end{array}$ & $\begin{array}{l}8 \cdot 5 \\
7 \cdot 8\end{array}$ & $\begin{array}{l}17 \cdot 0 \pm 0 \cdot 5 \\
19 \cdot 1 \pm 0 \cdot 5\end{array}$ & $\begin{array}{l}4 \cdot 3 \\
4 \cdot 0\end{array}$ & $\begin{array}{l}10 \cdot 5 \pm 0 \cdot 5 \\
12 \cdot 3 \pm 0 \cdot 6\end{array}$ \\
\hline C. dioscorides & $\begin{array}{l}1 \\
2\end{array}$ & $\begin{array}{l}87 \cdot 2 \pm 2 \cdot 2 \\
84 \cdot 8 \pm 1 \cdot 6\end{array}$ & $\begin{array}{l}22 \cdot 3 \\
21 \cdot 3\end{array}$ & $\begin{array}{l}41 \cdot 8 \pm 0 \cdot 5 \\
46 \cdot 4 \pm 1 \cdot 5\end{array}$ & $\begin{array}{l}10 \cdot 6 \\
11 \cdot 7\end{array}$ & $\begin{array}{l}10 \cdot 3 \pm 0 \cdot 4 \\
10 \cdot 4 \pm 0 \cdot 4\end{array}$ \\
\hline $\begin{array}{l}\text { C. capillaris } \\
\times \text { C. dioscorides }\end{array}$ & $\begin{array}{l}1 \\
2\end{array}$ & $\begin{array}{l}64 \cdot 3 \pm 1 \cdot 8 \\
69 \cdot 1 \pm 2 \cdot 1\end{array}$ & $\begin{array}{l}15 \cdot 1 \\
19 \cdot 8\end{array}$ & $\begin{array}{l}31 \cdot 1 \pm 1 \cdot 0 \\
33 \cdot 3 \pm 1 \cdot 0\end{array}$ & $\begin{array}{l}7 \cdot 3 \\
9 \cdot 6\end{array}$ & $\begin{array}{r}11 \cdot 1 \pm 0 \cdot 5 \\
9 \cdot 1 \pm 0.4\end{array}$ \\
\hline
\end{tabular}

* \pm standard error of the mean.

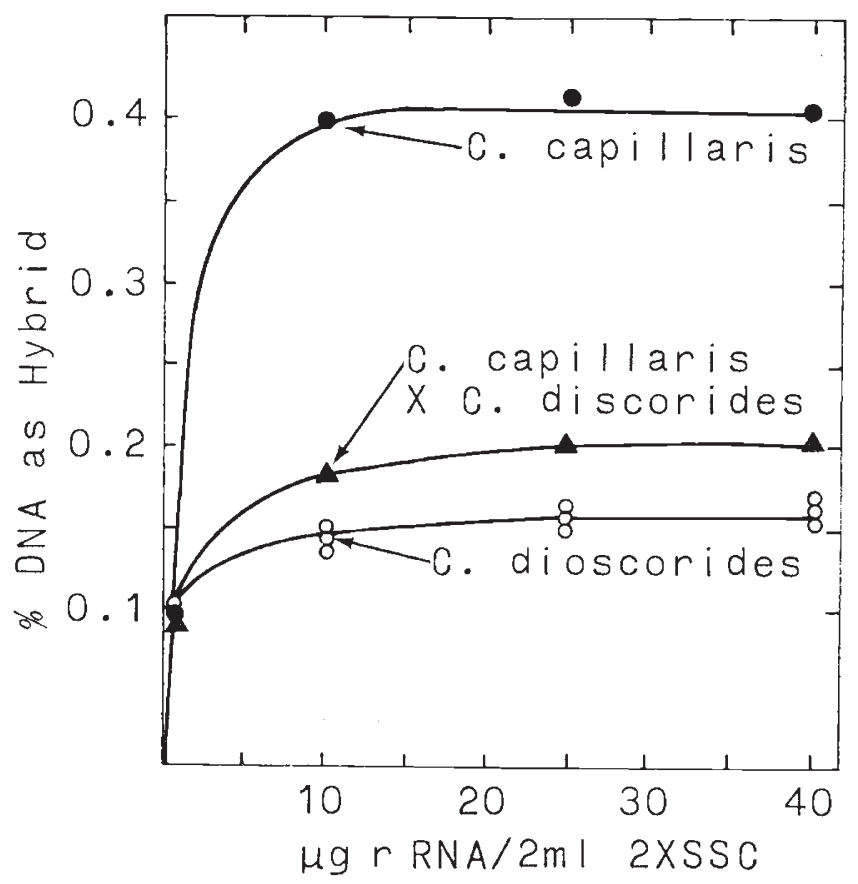

FIG. 1.-Saturation levels in rRNA/DNA hybridisation experiments. $30 \mu \mathrm{g}$ of the indicated DNA's were attached to membrane filters and incubated 15 hours at $65^{\circ} \mathrm{C}$ with increasing amounts of ${ }^{32} \mathrm{P}-\mathrm{rRNA}$.

in the hybrid. Three repetitions of the experiment (involving separate DNA extractions) showed the same relationship. 
The numbers of rRNA genes per haploid genome in the two parent species and hybrid were calculated from the data provided in table 1 and fig. 1 and are shown in table 2. Assuming a molecular weight of $2 \times 10^{6}$ daltons for the two rRNA types combined, the number of rRNA cistrons per haploid genome is about 2500. That number is as constant for the two parent species as it is for the hybrid. Thus, regardless of genome size, or of chromosomes with an active nucleolar organiser, the total amount of rDNA per diploid nucleus remains unchanged. Failure of nucleolar formations in the hybrid is clearly independent of rDNA presence.

TABLE 2

The number of $R$ RNA genes in a $2 c$ amount of $D \mathcal{N} A$ for Crepis capillaris, G. dioscorides, and the interspecific hybrid. The calculations were based on the following values. DNA contents: C. capillaris $\left(4 \cdot 1 \times 10^{-12} \mathrm{~g}\right)$, C. dioscorides $\left(11.0 \times 10^{-12} \mathrm{~g}\right)$, hybrid $\left(8.0 \times 10^{-12} \mathrm{~g}\right)$; molecular weight of $r R \mathcal{N A}\left(2 \times 10^{6}\right.$ daltons $)$

\begin{tabular}{lc}
\multicolumn{1}{c}{ Plant } & rRNA genes \\
C. capillaris & 4920 \\
C. dioscorides & 4950 \\
C. capillaris $\times$ C. dioscorides & 4800
\end{tabular}

\section{Discussion}

(i) Variation of $D \mathcal{N} A$

The evolution of the karyotype has been studied in at least 113 Crepis species representing 23 of the 27 taxonomic sections of the genus (Babcock, 1947). Progressive morphological and physiological changes within the genus were correlated with a decrease in haploid chromosome number from 6 to 3, such decrease having occurred by stepwise losses of single chromosomes. Paralleling the tendency toward reduction in chromosome number has been a trend toward reduction in chromosome size.

The species analysed in this study reflect both evolutionary trends. C. capillaris, the more advanced species, has three chromosomes per haploid set, (plate $\mathrm{I} a$ ), whereas $C$. dioscorides has four which are of larger size. Our finding that $C$. dioscorides has almost three times as much nuclear DNA as C. capillaris is in agreement with the cytological findings.

DNA content and evolutionary advancement was studied among nearly 1000 plant species and compared with DNA values for various taxonomic groups of organisms (Sparrow et al., 1972). Although a general trend of increasing DNA content with advancing organismic complexity was seen, within any given taxonomic group advancing complexity or evolutionary specialisation was often associated with decreasing DNA content. The nature of the DNA lost is unknown although it has been suggested that variation in the amount of redundant sequences may account for much of the DNA differences in higher organisms (Britten and Davidson, 1969; Flavell et al., 1974). Comparisons of DNA differences among closely related Vicia species as well as cytological comparisons of the chromosomes led to the conclusion that linear amplifications or deletions of sequences occurred at many sites throughout the chromosomes and account for the major 
proportion of DNA variation in Vicia (Chooi, 1971). Similar alterations are probably the basis for karyotype evolution in Crepis.

\section{(ii) $r D \mathcal{N} A$ constancy}

When the differences in DNA content between the two Crepis species and hybrid were taken into account, the calculations of number of rRNA genes per diploid genome revealed that all three contained about 5000 sequences complementary to 18 and 25S rRNA. This number is consistent with the high multiplicities of rRNA genes found in higher plants which range from a few thousand to over 20,000 copies (Birnstiel et al., 1971). The striking observation, however, was that even with almost a threefold difference in DNA between the two species, the amount of rDNA per cell remained constant. Either the NOR was not included in the chromosomal alterations leading to the two species or some stringent physiological requirement exists for this number of rRNA genes per cell. Support for the latter interpretation was found in comparisons of diploid and tetraploid Nicotiana species where there was a measured twofold difference in DNA content, but both had the same number of rRNA genes (Siegel et al., 1973). In a similar study of Nicotiana species Cullis (1975) found a similar relationship between the rRNA gene number of two tetraploids and their diploid progenitors.

\section{(iii) Explanations for the suppression of the nucleolar organiser}

The determinations of rRNA gene numbers presented here demonstrate clearly that no measurable loss of rDNA occurs concomitant with NOR suppression in the capillaris-dioscorides hybrid. The control of NOR activity then must be at the transcription level. Wallace and Langridge (1971), in a study of Crepis neglecta-C. capillaris hybrids suggested that differential suppression may be effected by allelic repression among the four iso-alleles found in the Crepis hierarchy of species. In their investigation they tried to differentiate between the rRNA's of the two species by base composition but did not present convincing evidence that the interspecific hybrid, exhibiting NOR suppression in the neglecta SAT chromosome, synthesised only capillaris rRNA. Thus there is yet no direct evidence that rRNA transcription is prevented by NOR suppression.

The hypothesis that NOR suppression would derive from a major reduction of rDNA was attractive inasmuch as it would point to a renewal of all reiterated rDNA at fertilisation. Our findings, however, do not support this idea.

Acknowledgment. - This research was made possible by a National Science Grant to Herbert Stern and grant number 5-R01-GM18663 from the National Institutes of Health to Earle B. Doerschug.

\section{RefERENGES}

Babcock, E. B. 1947. The Genus Crepis. University of California Publications in botany, Volume 21.

Berlyn, G. P., AND miksche, J. P. 1976. Botanical Microtechnique and Cytochemistry. Iowa State University Press, Ames, Iowa.

BIRNSTIEL, M. L., CHIPGHASE, M., AND SPEIRS, J. 1971. The ribosomal RNA cistrons. Prog. Nucleic Acid Res. Mol. Biol., 11, 351-389. 
BRITten, R. J., AND DAVIDSON, E. H. 1969. Gene regulation for higher cells: a theory. Science, 165, 349-357.

BURTON, K. 1968. Determination of DNA concentration with diphenylamine. Methods in Enzymol., XII P \& B, 163-166.

CHOor, w. Y. 1971. Variation in nuclear DNA content in the genus Vicia. Genetics, 68, 195-211.

collins, J. L. 1922. Culture of Crepis for genetic investigations. F. Hered., 13, 329.

DARLINGTON, C. D., AND LACOUR, L. F. 1962. The Handling of Chromosomes. George Allen and Unwin Ltd., London, 4th edition.

DOERschug, E. 1976. Placement of genes for ribosomal-RNA within the nucleolar organizing body of Zea mays. Chromosoma, in press.

ERIKSSON, T. 1965. Studies on the growth requirements and growth measurements of cell cultures of Haplopappus gracilis. Physiol. Plant., 18, 976-993.

FLAVELL, R. B., BENNETT, M. D., SMITH, J. B., AND SMITH, D. B. 1974. Genome size and the proportion of repeated nucleotide sequence DNA in plants. Biochem. Genet., 12, 257 269.

GILlESPIE, D., AND SPIEgELMAN, s. 1965. A quantitative assay for DNA-RNA hybrids with DNA immobilized on a membrane. 7. Mol. Biol., 12, 829-842.

Grvens, J. F. 1974. Molecular hybridization and cytological characterization of plants partially hyperploid for different segments of the nucleolus organizer region of Zea mays L. Ph.D. Thesis, University of Minnesota.

HEITZ, E. 1931. Die Ursache der gesetzmassigen Zehl, Lage, Form und Grosse pflanzlicher Nukleolen. Planta (Berl.), 12, 775-844.

HOTTA, Y., BASSEL, A., AND STERN, H. 1965. Nuclear DNA and cytoplasmic DNA from tissues of higher plants. 7. Cell Biol., 27, 451-457.

JACQMARD, A., MIKSCHE, J. P., AND BERNIER, G. 1972. Quantitative study of nucleic acids and proteins in the shoot apex of Sinapis alba during transition from the vegetative to the reproductive condition. Am. F. Bot., 59, 714-721.

KIRBY, K. s. 1965. Isolation and characterization of ribosomal ribonucleic acid. Biochem. 7 ., 96, 266-269.

MARMUR, J. 1961. A procedure for the isolation of deoxyribonucleic acid from microorganisms. 7. Mol. Biol., 3, 208-218.

NAVASHIN, M. 1934. Chromosome alterations caused by hybridization and their bearing upon certain general genetic problems. Cytologia, 5, 169-203.

PHILliPS, R. L., KLEEZE, R. A., AND WANG, S. s. 1971. The nucleolus organizer region of maize (Zea mays L.): Chromosomal site of DNA complementary to ribosomal RNA. Chromosoma (Berl.), 36, 79-88.

RAMIREZ, s. A., AND sINClair, J. H. 1975. Ribosomal gene localization and distribution (arrangement) within the nucleolar organizer region of Zea mays. Genetics, 80, 505518.

RITOSSA, F. M., AND SPIEGELMAN, s. 1965. Localization of DNA complementary to ribosomal RNA in the nucleolus organizer region of Drosophila melanogaster. Proc. Nat. Acad. Sci. U.S.A., 53, 737-745.

RitossA, F. M. 1968. Unstable redundancy of genes for ribosomal RNA. Proc. Nat. Acad. Sci. U.S.A., 60, No. 2, 509-516.

SIEGEL, A., LIGHTFOOT, D., WARD, O. G., AND KEENER, s. 1973. DNA complementary to ribosomal RNA: relation between genomic proportion and ploidy. Science, 179, 682683.

smith, G. P. 1973. Unequal crossover and the evolution of multigene families. Cold Spring Harb. Symp. Quant. Biol., 38, 507-514.

SOBER, H. A. 1970. Handbook of Biochemistry-Selected data for molecular biology. The Chemical Rubber Company, Cleveland, Ohio.

SPARROW, A. H., PRICE, H. J., AND UNDERbrink, A. G. 1972. A survey of DNA content per cell and per chromosome of prokaryotic and eukaryotic organisms: some evolutionary considerations. In Evolution of Genetic Systems, ed. H. H. Smith et al. pp. 451-494. Gordon and Breach, New York.

sueOKA, N., AND CHENG, T. 1962. Fractionation of nucleic acids with the methylated albumin column. 7. Mol. Biol., 4, 161-172.

TARTOFF, K. D. 1971. Increasing the multiplicity of ribosomal RNA genes in Drosophila melanogaster. Science, 171, 294.

TARTOFF, K. D. 1973. Unequal mitotic sister chromatid exchange and disproportionate replication as mechanisms regulating ribosomal RNA gene redundancy. Cold Spring Harb. Symp. Quant. Biol., 38, 475-482. 
TjIO, J. H., AND LEVAN, A. 1950. The use of oxyquinoline in chromosome analysis. An estac. Exp. Aula Dei Zaragoza, 2, 21-64.

WALlACE, H., AND BIRNSTIEL, M. L. 1966. Ribosomal cistrons and the nucleolar organizer. Biochem. Biophys. Acta, 144, 296-310.

WALlAcE, H., AND LANGRIDGE, W. H. R. 1971. Differential amphiplasty and the control of ribosomal RNA synthesis. Heredity, 27, 1-13. 